\title{
Effects of Cynanchi Wilfordii Radix and Polygoni Multiflori Radix liquors on lipid peroxidation and antioxidant activity in rat serum amd brain tissue
}

\author{
Hyeun-Ju Kong, Kyung-Mi Yang* \\ Faculty of Herbal Food Cooking \& Nutrition, Daegu Haany University, Gyeongsan 38578, Korea
}

\section{백·적하수오 담금주를 섭취한 흰쥐의 혈청과 뇌 조직의 과산화지질 수준 및 항산화 효소 활성 상태}

\author{
공현주 · 양경미* \\ 대구한의대학교 한방식품조리영양학부
}

\begin{abstract}
This study was conducted to identify the effects of Cynanchi Wilfordii Radix and Polygoni Multiflori Radix liquors on lipid peroxidation and antioxidant activity in rats. Male Sprague-Dawley rats were placed on a liquid diet for six weeks. The rats were assigned to one of four experimental groups according to the following liquid diet types: a normal liquid diet (C), the soju liquid diet (A), a Cynanchi Wilfordii Radix liquor diet (WA) and a Polygoni Multiflori Radix liquor diet (RA). Except group C, alcohol contributed $12 \%$ of the total calories consumed by the rats. The results of MDA level and antioxidant activity of serum and brain tissue of rats were as follows. The serum and brain MDA levels of WA and RA groups could be lowered to the group C level. The nitric oxide (NO) level of the brain tissue of the RA group was lowest in all the groups. Serum superoxide dismutase (SOD) activity in the A and WA groups were significantly elevated. Serum catalase activity was significantly higher in the WA group than it was in groups C and A. Glutathione peroxidase (GSH-Px) activity in brain tissue was significantly elevated in the WA and RA groups relative to group A. Among all the experimental groups, the total serum antioxidant capacity in group $\mathrm{A}$ was lowest. This indicated the soju liquid diet led to oxidative damage in these rats. In contrast, the Cynanchi Wilfordii Radix and Polygoni Multiflori Radix liquor diets effectively inhibited lipid peroxidation and NO production.
\end{abstract}

Key words : Cynanchi Wilfordii Radix, Polygoni Multiflori Radix, soaking liquor, oxidative stress, antioxidant activity

\section{서 론}

복잡한 사회경제 구조에 따른 과도한 경쟁과 스트레스로 인한 고도음주자가 늘어나면서 이들의 심각한 건강문제로 인해 천연물로 제조된 건강기능성 식품이나 약용식물로 만든 담금주에 대한 관심이 높아지고 있다. 만성적으로 다

*Corresponding author. E-mail : jiboosin@dhu.ac.kr Phone : 82-53-819-1490, Fax : 82-53-819-1494

Received 07 February 2019; Revised 20 March 2019; Accepted 28 March 2019.

Copyright (c) The Korean Society of Food Preservation. All rights reserved.
량의 알코올을 섭취 할 경우 면역기능 손상, 고지혈증, 위장 장애 이외에 지방간을 포함한 알코올성 간질환이나 여러 종류의 건강장해가 유발된다 $(1,2)$. 특히, 고용량의 알코올 에 노출될 경우 기억력을 관장하는 해마 및 대뇌피질의 $\mathrm{GABA}$ 와 glutamate의 불균형으로 알코올성 블랙아웃(black out)과 같은 알코올성 기억장애 및 알코올성 치매 등 뇌 질환을 일으켜서 개인의 건강과 삶의 질을 떨어뜨려 사회적 으로 큰 문제가 되고 있다 $(3,4)$. 현재까지 알코올에 의한 신경계 독성의 원인 및 작용 기전에 대해서는 명확히 밝혀 지지 않고 있으나 nitric oxide(NO)의 과다 생성과 같은 산화 적 스트레스가 원인으로 알려져 있다(5).

알코올에 의한 산화적 스트레스는 알코올 자체뿐만 아니 
라 알코올 대사산물인 acetaldehyde와 활성산소(reactive oxygen species, ROS)와 같은 자유라디칼(free radicals)의 과도한 생성으로 유발된다. 그 결과 과산화지질의 증가나 항산화 활성의 손상 등으로 인해 뇌 세포 손상과 기억력 저하가 일어나는 것으로 보고되고 있다(6,7). 그러나 알코 올의 산화적 스트레스에 대한 생체 방어로는 superoxide dismutase(SOD), glutathione peroxidase(GSH-Px), catalase 등의 효소적 방어체계 및 비타민 $\mathrm{A}, \mathrm{E}, \mathrm{C}$ 등의 항산화 비타 민 및 polyphenol, flavonoid 등의 생리활성 물질인 비효소적 방어체계가 있다 $(1,8)$. 최근에는 flavonoid의 신경계에 대한 보호효과에 관한 연구에 대해 활발히 진행되고 있으며, 그 기전으로 flavonoid는 산화적 스트레스에 의한 자유라디칼 의 효과적인 제거를 통해 일어나는 것으로 알려지고 있다 (9).

천연물 중 백하수오(Cynanchi wilfordii radix) 뿌리에서 추출된 시난콜(cynanchol), 사코스틴(sarcostin) 등의 생리활 성물질과 배당체(gagaminine) 성분은 자유라디칼 소거 기 능을 통하여 과산화지질 생성과 acetaldehyde의 산화 활성 을 저해시킨다(10). 이러한 기전을 통해 백하수오는 항노화, 자양강장, 보혈작용 이외에도 동맥경화 억제 효과, 고지혈 증 및 당뇨 예방 개선 효과, 혈관이완 효과를 보이는 것으로 밝혀졌다(11). 그 반면에, anthraquinone 화합물인 chrysophanol, emodin, rhein, physcion 및 2,4,6,4'-tetrahydroxystilbene-2-O$\beta$-D-glucoside를 비롯한 배당체를 함유하고 있는 적하수오 (Polygoni multiflori radix)는 항균(12), 항암(13), 항산화(14), 항염증(15) 및 신경보호(16) 효과 등이 보고되었다. 백하수 오에 대한 생체 효능 연구결과로는 분쇄된 백하수오 $2 \mathrm{~kg}$ 을 $80 \%$ 에탄올로 추출한 추출물을 Sprague-Dawley (SD) 흰쥐 에게 투여하였을 때, 혈압 저하 작용과 함께 지질대사 개선 효과를 보였다(17). 또한 고지방식이를 섭취한 실험동물에 게 ethyl acetate로 추출한 백하수오 추출물을 6주간 공급한 결과, 과산화지질 억제와 항산화 효소 활성을 유의하게 증 가시키는 것으로 나타났다(18). 이외에도 고지방 식이 공급 으로 혈관 손상이 유도된 실험동물에게 백하수오 추출물을 공급한 결과, 백하수오의 구성성분인 gagaminine, wilfoside 등에 의해 항산화 효과 및 비정상적 혈관 생성의 억제로 혈관 기능이 개선되었다고 보고되었다(19).

허혈성 뇌손상을 억제하고 산화적 손상에 의한 동맥경화 예방작용 및 학습 능력과 기억력 개선 효과가 있는 적하수 오를 수준별로 첨가하여 만든 약용주에서는 발효 기간이 증가하면서 총 phenol 함량의 증가현상이 관찰되었다(20). 치매환자 등에 대한 기억력 개선 약물로는 뇌 조직의 신경 전달물질인 acethylcholine의 분해 효소인 acethylcholin esterase(ACh-E) 효소 활성을 억제하여 뇌 속의 acethylcholine 농도를 증가시키는 방법이 이용되고 있다(21). Won 등(22) 은 $\mathrm{ACh}-\mathrm{E}$ 효소 활성 억제 효과는 미나리 추출물의 flavonoids와 phenol 성분에 의한 것이며, 그 기전은 이들
성분의 항산화 활성을 통해 산화적 스트레스를 감소시킴으 로써 기억력을 개선시키는 것으로 설명하고 있다. 그러나 현재까지 동물 및 임상 연구영역에서 하수오의 항산화 활성 이나 기억력 개선 효과에 대한 미흡한 실정이다.

본 연구진의 선행된 연구(7)에서는 백하수오 및 적하수 오 담금주를 섭취했을 때 담금 소주를 섭취한 경우 보다 혈청과 뇌 조직 내의 acethylcholine 농도는 높은 반면에, $\mathrm{ACh}-\mathrm{E}$ 효소는 억제효과를 보였다. 이러한 결과는 담금 소 주보다는 백하수오 담금주나 적하수오 담금주를 마셨을 때 기억력 손상을 감소시킬 수 있을것으로 기대된다. 이에 본 연구에서 백하수오와 적하수와 담금주의 섭취에 따른 기억력 손상에 대한 조절기전으로서 하수오 담금주의 항산 화력을 규명하기 위하여 하수오 담금주를 섭취한 흰 쥐의 혈청과 뇌 조직의 과산화지질 함량 및 항산화 효소 활성을 분석하였다.

\section{재료 및 방법}

\section{하수오 담금주 제조}

본 실험에서는 경상남도 하동에서 직접 채취한 백하수오 와 적하수오 뿌리를 사용하였다. 하수오 담금주 제조는 $\mathrm{Hwa}(23)$ 의 제조방법에 의거하였으며, 구체적인 제조 방법 으로는 백하수오와 적하수오 뿌리를 일반 음용수로 깨끗이 세척한 다음 그늘에서 일정 시간 동안 수분을 제거하였다. 그런 다음 백하수오와 적하수오 뿌리를 각각 $95 \mathrm{~g}$ 씩 취한 다음 일반가정에서 사용하는 $30 \%$ 담금 소주(참이슬 담금 주, Jinro, Changwon, Korea)를 넣어 $1 \mathrm{~L}$ 가 되도록 하였다. 이렇게 제조된 담금주는 밀봉용기에 담은 다음 음지에서 6년 정도 숙성시킨 후 개봉하였다. 개봉된 하수오 담금주의 알코올 함량를 주정계(ATAGO, Tokyo, Japan)로 측정한 결 과, 백하수오 담금주는 $30.5 \%$, 적하수오 담금주는 $31.0 \%$ 이 었다. 각각의 하수오 담금주에 증류수를 가하여 $25 \%$ 알코 올 농도로 희석 한 다음 액체 실험식이(liquid diet)로 만들어 서 실험동물에게 공급하였다.

\section{실험동물 및 식이}

체중이 300-350 g 정도의 생후 10 주령이 된 수컷 SD계 흰쥐를 효창사이언스(Hyochang Science, Daegu, Korea)에 서 구입하여 사용하였다. 실험동물의 사육실 환경온도는 $22 \pm 1{ }^{\circ} \mathrm{C}$, 상대습도는 $65 \pm 5 \%$, 명암은 12 시간 주기(09:0021:00)로 조절하였다. 2주 적응기간 동안 실험동물은 일반 배합 고형사료(Jeil, Feed Co., Ltd. Korea)와 음용수를 자유 롭게 섭취하였다. 그런 다음 난괴법에 의거하여 4 개의 실험 군으로 무알코올 섭취군(C), $25 \%$ 담금 소주 섭취군(A), 백 하수오 담금주 섭취군(WA), 적하수오 담금주 섭취군(RA) 으로 나눈 다음, 각 처리 군당 10 마리씩 각각의 cage에서 
6주 동안 알코올이 함유된 액체 실험식이를 공급하였다. 액체 실험식이는 Table 1 과 같이 무알코올 섭취군은 설탕으 로, 알코올 섭취군은 $25 \%$ 알코올(담금 소주, 백하수오 담금 주, 적하수오 담금주)를 각각 첨가하여 증류수로 용해시켜 제조하였다. 이때 액체 실험식이는 $1 \mathrm{~mL}$ 당 $1 \mathrm{kcal}$ 열량을 공급할 수 있도록 조제하였으며, 알코올 섭취량은 전체 열 량의 $12 \%$ 로 조정하였다(24). 액체 실험식이와 물은 자유로 이 섭취할 수 있게 하였으며, 실험기간 중 식이조제는 매일 제조하여 냉장보관하여 신선한 상태로 공급하였다. 본 연 구에서의 모든 실험동물의 구입과 사육의 모든 과정은 대구 한의대학교 동물실험윤리위원회의 승인 하에 실시되었다 (DHU 2015-045).

Table 1. Composition of liquid diets used in experiment

$(\mathrm{g} / \mathrm{L})$

\begin{tabular}{|c|c|c|c|c|}
\hline \multirow{2}{*}{ Ingredient } & \multicolumn{4}{|c|}{ Group $^{1)}$} \\
\hline & $\mathrm{C}$ & A & WA & RA \\
\hline Casein & 41.4 & 41.4 & 41.4 & 41.4 \\
\hline L-Cystine & 0.5 & 0.5 & 0.5 & 0.5 \\
\hline DL-Methionine & 0.3 & 0.3 & 0.3 & 0.3 \\
\hline Corn oil & 7.8 & 7.8 & 7.8 & 7.8 \\
\hline Olive oil & 14.2 & 14.2 & 14.2 & 14.2 \\
\hline Sucrose & 149.5 & 120.2 & 120.2 & 120.2 \\
\hline Choline bitartrate & 0.5 & 0.5 & 0.5 & 0.5 \\
\hline a-Cellulose & 10 & 10 & 10 & 10 \\
\hline Xanthan gum & 3 & 3 & 3 & 3 \\
\hline Vitamin mixture $^{2)}$ & 2.6 & 2.6 & 2.6 & 2.6 \\
\hline Mineral mixture ${ }^{3)}$ & 9 & 9 & 9 & 9 \\
\hline $25 \%$ Soju & - & 84.5 & - & - \\
\hline 25\% Cynanchum wilfordii radix liquor & - & - & - & 84.5 \\
\hline 25\% Polygonum mulyiflorum radix liquor & - & - & 84.5 & - \\
\hline $\begin{array}{l}\text { 1) C, normal liquid diet; A, 25\% Soju addition } \\
\text { Wilfordii Radix liquor addition to liquid die } \\
\text { liquor addition to liquid diet. } \\
\text { 2) AIN-93G-MX. } \\
\text { 3) AIN-93G-VX. }\end{array}$ & liqu & iet; $y$ & $25 \%$ & nanchum \\
\hline
\end{tabular}

\section{시료채취}

실험동물은 12 시간 절식시킨 후, $\mathrm{CO}_{2}$ 로 가볍게 마취시켜 개복한 즉시 복부대동맥에서 재취한 혈액을 실온에서 약 30 분간 방치한 후 $3,000 \mathrm{rpm}$ 에서 15 분간 냉장상태에서 원 심분리하여 얻은 혈청을 실험에 사용하였다. 뇌 조직은 단 두법으로 처리하여 적출한 즉시 여과지로 물기를 제거한 다음 무게를 측정한 후, 알루미늄 호일로 포장하여 액체 질소로 급속 냉동시켜 $-70^{\circ} \mathrm{C}$ 에서 냉동보관하여 실험에 사 용하였다. 실험 사용 직전 뇌 조직의 일부를 취해서 조직균 질기(HS-30E, DAEHAN Scientific, Wonju, Korea)를 사용
하여 냉장 상태에서 $1.15 \% \mathrm{KCl}$ 완충용액을 이용하여 $10 \%(w / v)$ 마쇄 균질액을 만들었다. 그런 다음 Mitochondria/ cytosol fractionation kit(\#K256-25, Biovision, St. Louis, MO, USA)를 이용하여 미토콘드리아와 사이토졸 분획을 획득 하였다. 분리한 미토콘드리아 균질액은 과산화지질 (malodialdehyde, MDA), NO 생성능, total antioxidant capacity(TAC) 수준 및 catalase와 GSH-Px 활성 측정에 이용 하였으며, 사이토졸 균질액은 superoxide dismutase(SOD) 및 glutathione-s-transferase(GST) 활성 측정에 이용하였다.

\section{과산화지질 함량}

과산화지질 함량은 혈청과 뇌 미토콘드리아 균질액 10 $\mu \mathrm{L}$ 를 시료로 취하여 thiobarbituric acid(TBA)와 반응하여 생성된 물질을 정량하는 $\mathrm{MDA}$ 정량용 $\mathrm{kit}(\# \mathrm{CAK} 1011$, Biovision, St Louis, MO, USA)로 측정하였다. 시료 $10 \mu \mathrm{L}$ 에 $42 \mathrm{mM} \mathrm{H}_{2} \mathrm{SO}_{4} 500 \mu \mathrm{L}$ 와 phosphotungstic acid $125 \mu \mathrm{L}$ 를 가하 여 잘 섞어준 다음 실온에서 5 분 동안 방치한 뒤 13,000 $\times \mathrm{g}$ 에서 3 분 동안 원심분리하였다. 그런 다음 상층액 100 $\mu \mathrm{L}$ 을 취한 후 $\mathrm{H}_{2} \mathrm{O} 100 \mu \mathrm{L}$ 를 첨가하였다. 그 후 $\mathrm{TBA} 600$ $\mu \mathrm{L}$ 를 넣고 $95^{\circ} \mathrm{C}$ 에서 60 분 동안 방치 한 다음 ice bath안에서 10 분 동안 냉각시킨 반응 혼합물을 각각의 well에 200 $\mu \mathrm{L}$ 씩을 넣고 microplate reader(N10583, Thermo Scientific, Waltham, MA, USA) 사용하여 $532 \mathrm{~nm}$ 에서 측정하였다.

\section{Nitric oxide 생성능}

Nitric oxide 생성능은 Griess 용액을 이용하여 NO로부터 생성된 nitrate 및 nitrite 함량을 측정하는 NO 정량용 kit(\#K262-200, Biovision, St Louis, MO, USA)를 이용하였 다. 혈청과 뇌 조직 균질액의 상층액 $10 \mu \mathrm{L}$ 취한 후 assay buffer $85 \mu \mathrm{L}$ 와 assay buffer $115 \mu \mathrm{L}$ 를 가하여 최종적으로 $200 \mu \mathrm{L}$ 로 채웠다. 그런 다음 시료가 담긴 96-well plate에 nitrate reductase mixture와 enzyme cofactor 용액을 각각 5 $\mu \mathrm{L}$ 씩 첨가 한 후 1 시간 동안 실온에서 반응시켰다. 그 후 각각의 well에 enhancer $5 \mu \mathrm{L}$ 첨가 후 실온에서 10 분간 방치 다음 Griess reagent $50 \mu \mathrm{L}$ 씩 넣었다. 그런 다음 실온에서 10 분간 둔 다음 microplate reader(N10583, Thermo Scientific)를 이용하여 $540 \mathrm{~nm}$ 에서 흡광도를 측정하였다.

\section{Superoxide dismutase 활성}

Superoxide dismutase 활성 측정은 $\mathrm{O}_{2}{ }^{-}$에 의하여 WST-1 (2-(4-idophenyl)-3-(4- nitrophenol)-5-phenyl tetrazoliumchloride) 을 WST-1 formazan으로 환원시키는데, 이때 SOD 효소가 이 반응을 저해한다는 원리를 이용한 SOD 효소 활성 측정 용 kit(\#K335-100, Biovision, St Louis, MO, USA)를 이용하 여 측정하였다. 시료 $10 \mu \mathrm{L}$ 에 증류수 $20 \mu \mathrm{L}$ 를 넣은 다음 각각의 well에 WST working solution $200 \mu \mathrm{L}$ 를 첨가하였다. 그런 다음 dilution buffer $20 \mu \mathrm{L}$ 와 enzyme working solution 
$20 \mu \mathrm{L}$ 를 첨가하였다. 이 혼합액을 $37^{\circ} \mathrm{C}$ 인큐베이터 (VS-1205SW1, Vision Scientific Co, Daejeon, Korea)에서 20 분 동안 배양하고 microplate reader(N10583, Thermo Scientific)를 이용하여 $450 \mathrm{~nm}$ 에서 흡광도를 측정하였다. 효소의 활성단위(unit)는 WST-1 formazan의 환원을 $50 \%$ 저지하는 $\mathrm{SOD}$ 량으로 계산하여 단백질 값으로 보정하여 나타내었다.

\section{Catalase 활성}

Catalase 활성은 $\mathrm{H}_{2} \mathrm{O}_{2}$ 의 가수분해 정도를 측정한 catalase 측정용 kit(\#K773-100, Biovision, St Louis, MO, USA)를 이용하였다. 각각의 시료를 catalase assay buffer로 희석하 여 원심분리 한 후 상층액을 시료로 이용하였다. Catalase 활성은 각각의 well에 $1 \mathrm{mM} \mathrm{H}_{2} \mathrm{O}_{2} 12 \mu \mathrm{L}$ 를 넣고 $25^{\circ} \mathrm{C}$ 에서 30 분 동안 배양한 후 stop solution을 첨가하여 측정하였다. 시료 $10 \mu \mathrm{L}$, assay buffer $46 \mu \mathrm{L}$, OxiRed ${ }^{\mathrm{TM}}$ Probe $2 \mu \mathrm{L}$, HRP solution $2 \mu \mathrm{L}$ 를 첨가한 후 잘 섞은 다음 $25^{\circ} \mathrm{C}$ 에서 10 분간 배양하고 microplate reader(N10583, Thermo Scientific)를 이용하여 $570 \mathrm{~nm}$ 에서 $\mathrm{H}_{2} \mathrm{O}_{2}$ 분해에 따른 흡광도를 측정하였 다. 효소의 활성단위(unit)는 $\mathrm{H}_{2} \mathrm{O}_{2}$ 를 분해시킬수 있는 효소 의 양을 단백질 $1 \mathrm{mg}$ 당 1 분간 반응 정도로 나타내었다.

\section{Glutathione-s-transferase 활성}

Glutathione-2-transferase 활성은 환원형 glutathione(GSH) 와 GST 기질인 $\mathrm{CDNB}$ (1-chloro-2,4-dinitrobezene) 반응을 유도하여 생성된 GS-DNB(2,4-dinitrobenzene glutathione) 화합물을 생성하는 nitrobenzene 효소 활성을 측정하는 GST activity assay kit(\#K263-100, Biovision, St Louis, MO, USA)를 이용하여 측정하였다. $10 \mu \mathrm{L}$ 시료에, GST assay buffer $40 \mu \mathrm{L}$ 를 넣고 총 용량을 $50 \mu \mathrm{L}$ 로 맞춘 다음 각각의 well에 GSH 용액 $5 \mu \mathrm{L}$ 을 첨가 하였다. 그런 다음 GST assay buffer $45 \mu \mathrm{L}$ 와 GST substrate(CDNB) solution $5 \mu \mathrm{L}$ 을 넣어 혼합한 후 microplate reader(N10583, Thermo Scientific)를 이용하여 $340 \mathrm{~nm}$ 에서 흡광도를 측정하였다. 효소의 활성단위(unit)는 1 분 동안 단백질 $1 \mathrm{mg}$ 이 생성한 GS-DNB의 $340 \mathrm{~nm}$ 에서의 흡광계수로 환산하여 나타내었 다.

\section{Glutathione-peroxidase 활성}

Glutathione-peroxidase 활성은 NADPH 감소로 효소 활성 을 측정하는 GSH-Px activity assay $\mathrm{kit}(\# \mathrm{~K} 261-100$, Biovision, St Louis, MO, USA)를 이용하여 측정하였다. 시 료는 PBS로 재현탁 한 후 glutathione buffer $80 \mu \mathrm{L}$ 를 넣고 10 분간 냉동 상태에서 배양한 후 $5 \%$ 의 sulfosalicylic acid $20 \mu \mathrm{L}$ 를 첨가 하였다. 그리고 10 분 동안 $8,000 \times \mathrm{g}$ 에서 원심 분리 한 후 상층액을 시료로 사용하였다. 각 well에 NADPH generating mixture $20 \mu \mathrm{L}$, glutathione reductase $20 \mu \mathrm{L}$, glutathione reaction buffer $120 \mu \mathrm{L}$ 를 넣고 실온에서 10 분간 반응시켜 NADPH를 생성하였다. 그런 다음 $1 \%$ sulfosalic acid를 첨가하고 시료 $100 \mu \mathrm{L}$ 를 넣고 10 분간 배양한 후 substate solution $20 \mu \mathrm{L}$ 를 첨가하여 실온에서 10 분 배양한 다음 microplate reader(N10583, Thermo Scientific)를 이용 하여 $405 \mathrm{~nm}$ 에서 흡광도를 측정하였다. GSH-Px 효소 활성 은 1 분 동안 $1 \mu \mathrm{M} \mathrm{NADPH}$ 를 산화시키는 효소의 양을 1 unit로 계산하였으며, 단백질 값으로 보정하였다.

\section{Total antioxidant capacity 측정}

Total antioxidant capacity 측정은 trolox equivalent antioxidant capacity법에 따라 분석하는 $\mathrm{TAC}$ 측정용 kit(\#K274-100, Biovision, St Louis, MO, USA)를 이용하여 분석하였다. $10 \mu \mathrm{L}$ 시료에 $0,4,8,12,16,20 \mathrm{nmol}$ 의 trolox 표준용액을 각각 $10 \mu \mathrm{L}$ 취한 다음 모든 well에 $\mathrm{H}_{2} \mathrm{O} 100$ $\mu \mathrm{L}$ 를 첨가한 후 $\mathrm{Cu}^{2+}$ working solution $100 \mu \mathrm{L}$ 첨가하여 1.5 시간 정도 상온에 방치한 후 micro plate reader(N10583, Thermo Scientific)를 이용하여 $570 \mathrm{~nm}$ 에서 흡광도를 측정 하였다.

\section{통계처리}

실험을 통하여 얻어진 자료는 SPSS 통계 package(version 21.0)를 이용하여 분석하였으며 그 결과는 평균표준편차 (standard error)로 표시하였다. 실험결과는 일원배치 분산 분석(one way analysis of variance)을 한 후 Duncan's multiple-range test에 의해 $\mathrm{p}<0.05$ 수준에서 각 실험군의 평균치의 통계적 유의성을 검정하였다.

\section{결과 및 고찰}

\section{과산화지질 수준}

혈청과 뇌 조직의 $\mathrm{MDA}$ 수준은 Fig. 1 과 같다. 혈청의 $\mathrm{MDA}$ 함량은 $\mathrm{C}$ 군, $\mathrm{A}$ 군, $\mathrm{WA}$ 군, $\mathrm{RA}$ 군은 각각 $0.33,0.57$, $0.37,0.51 \mathrm{nmol} / \mathrm{mg}$ protein으로 $\mathrm{C}$ 군에 비해 $\mathrm{A}$ 군에서 $\mathrm{p}<0.05$ 수준에서 $72.7 \%$ 의 유의적인 증가를 보였으나, WA군과는 유의적인 차이가 없었다. 뇌 조직의 $\mathrm{MDA}$ 함량은 $\mathrm{C}$ 군, $\mathrm{A}$ 군, WA군, RA군은 각각 $0.32,0.43,0.35,0.36 \mathrm{nmol} / \mathrm{mg}$ protein 수준으로 $\mathrm{C}$ 군에 비해 $\mathrm{A}$ 군에서 $\mathrm{p}<0.05$ 수준에서 유의적으 로 높았으며, $\mathrm{WA}$ 군과 RA군과는 유의적인 차이가 없었다.

백하수오와 적하수오는 기원식물과 유기성분도 다르다. 백하수오는 박주과리과(Asclepiadaceae) 식물의 덩이뿌리 로서 steroids, alkaloids, terpenes, flavonoids, steroidal glycosides 등의 생리활성 성분을 함유하고 있다(25). 적하 수오는 마디풀과(Polygonaceae) 식물의 덩이뿌리로서 적하 수오 뿌리에는 anthraquionone 화합물인 chrysophanol, emodin, rhein physcion 및 이들의 배당체인 2,3,5,4'- 
tetrahydroxystibene 2-O- $\beta$-D-glucopyranoside 및 2'-Omongalloyl ester 등이 함유되어 있다. 이들 성분 가운데 항산화 효능으로 알려져 있는 emodin의 함량이 많을수록 적하수오의 품질이 우수한 것으로 평가되고 있다. 이외에 도 하수오의 항산화력은 유기성분 중 총 polyphenol과 총 flavonoid 함량에 따라 항산화 활성력이 좌우된다(26). Seo 등(27)의 보고에 의하면 백하수오와 적하수오의 총 polyphenol과 flavonoid 함량 및 ABTS radical 소거능에서도 백하수오에 비해 적하수오에서 우수한 것으로 나타났다. 동물실험에서는 백하수오 및 적하수오는 사염화탄소 및 고콜레스테롤 식이로 산화 스트레스를 가한 쥐의 간 조직 내에서 자유라디컬 소거능, $\mathrm{MDA}$ 생성 저하, 이상지질혈증 및 혈당 대사 조절을 통해 간 손상 보호 효과가 있으며 $(28,29)$, 사염화탄소로 간 독성이 유도된 흰쥐의 간 독성 완화 효과는 적하수오 보다 백하수오가 더 우수한 것으로 보고되었다(30).

본 실험에서 알코올의 섭취에 따른 산화적 스트레스을 평가하기 위해 지표물질인 과산화지질인 $\mathrm{MDA}$ 수준을 분 석한 결과, 담금 소주를 섭취 한 실험동물의 혈청과 뇌 조직 에서 $\mathrm{MDA}$ 수준이 증가 되었다. 그러나 혈액 내 $\mathrm{MDA}$ 함량 은 담금 소주 대신에 백하수오 담금주를 섭취했을 때, 뇌 조직의 $\mathrm{MDA}$ 함량은 백하수오 및 적하수오 담금주의 섭취 로 비슷한 감소 효과를 얻을 수 있었다.

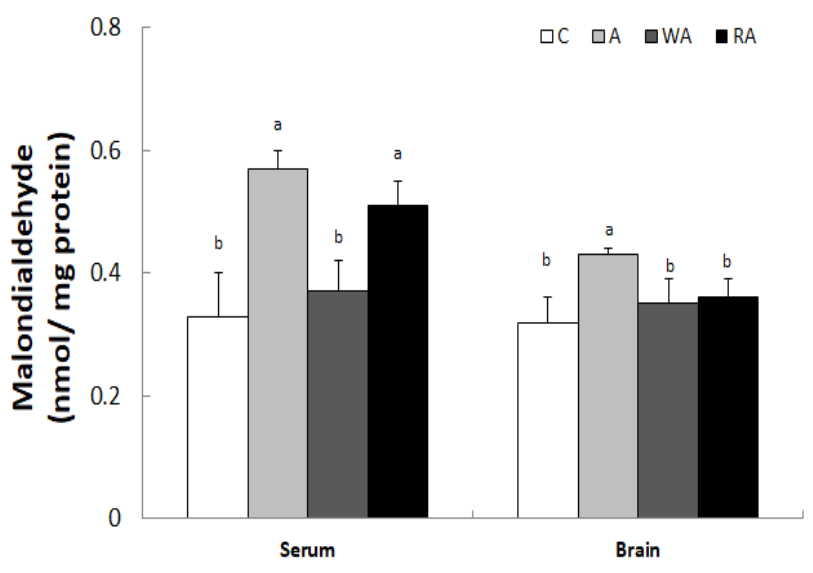

Fig. 1. Influences of chronical Cynanchi Wilfordii Radix and Polygoni Multiflori Radix liquors ingestion on serum and brain MDA levels in rats.

C, normal liquid diet; A, 25\% Soju addition to liquid diet; WA, 25\% Cynanchum Wilfordii Radix liquor addition to liquid diet; RA, 25\% Polygoni Multiflori Radix liquor addition to liquid diet.

Values are means $\pm \mathrm{SD}, \mathrm{N}=10$, Values with different alphabet are significantly different at $p<0.05$ by Duncan's multiple range test.

\section{Nitric oxide 생성능}

혈청과 뇌 조직의 $\mathrm{NO}$ 수준 결과는 Fig. 2와 같다. 혈청의 $\mathrm{NO}$ 생성능은 $\mathrm{C}$ 군, $\mathrm{A}$ 군, WA군, RA군에서 각각 $0.34,0.33$, $0.31,0.30 \mathrm{nmol} /$ well protein으로 모든 군 간에 유의적인
차이가 없었다. 뇌 조직에서는 $\mathrm{C}$ 군, $\mathrm{A}$ 군, $\mathrm{WA}$ 군, $\mathrm{RA}$ 군은 각각 $0.23,0.19,0.19,0.14 \mathrm{nmol} / \mathrm{well}$ protein으로 $\mathrm{C}$ 군에 비해 $\mathrm{RA}$ 군에서 유의적인 감소를 보였다 $(\mathrm{p}<0.05)$. 생체 내에서 $\mathrm{NO}$ 은 중요한 생리적 조절인자로 작용하지만 $\mathrm{NO}$ 수준에 따라 이중적 생물학적 기능을 보인다. 인체 내 저 수준의 $\mathrm{NO}$ 는 신경전달물질 등의 작용을 보이지만, 과도한 $\mathrm{NO}$ 생 성은 $\mathrm{ROS}$ 와 반응하여 $\mathrm{ONOO}^{-}$라디칼과 같은 반응성 산화 물질을 생성하여 $\mathrm{ONOO}^{-}$라디칼에 의한 조직의 병적인 산 화적 손상을 유발하여 급.만성 염증을 일으킨다(31). 그러 나 DPPH, ABTS 및 hydroxyl radical 소거능 효과가 증명된 법제 적하수오 메탄올 추출물을 산화적 스트레스가 가해진 LLC-PK1 cell에 투여한 결과, 과잉의 NO로부터 생성된 $\mathrm{ONOO}^{-}$라디컬과 같은 반응성 질소 매개체 소거능으로 산 화적 스트레스에 대한 개선 효과를 보였으며, 이때 적하수 오의 유효성분은 2,3,5,4'-tetrahydroxystilbene 2-O- $\beta$-Dglucoside로 보고되었다(32). 본 연구에서 알코올 섭취에 따른 산화 스트레스로 NO 생성능을 측정한 결과, 혈장의 $\mathrm{NO}$ 생성능은 모든 실험군 간에 유의적인 차이는 없었으나 뇌 조직에서는 무알코올 섭취군에 비해 적하수 담금주 섭취 군에서 NO 생성능 저해에 긍정적인 효과를 보였다.

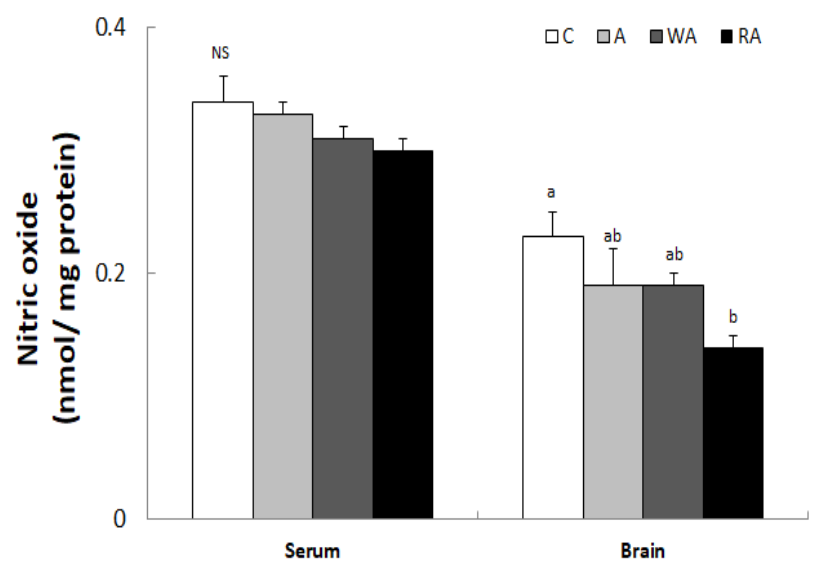

Fig. 2. Influences of chronical Cynanchi Wilfordii Radix and Polygoni Multiflori Radix liquors ingestion on serum and brain NO levels in rats.

C, normal liquid diet; A, 25\% Soju addition to liquid diet; WA, 25\% Cynanchum Wilfordii Radix liquor addition to liquid diet; RA, 25\% Polygoni Multiflori Radix liquor addition to liquid diet.

Values are means \pm S.D., $N=10$, Values with different alphabet are significantly different at $\mathrm{p}<0.05$ by Duncan's multiple range test.

\section{Superoxide dismutase 활성}

혈청과 뇌 조직의 $\mathrm{SOD}$ 활성은 $\mathrm{Fig}$. 3과 같다. 혈청에서는 C군, A군, WA군, RA군은 각각 69.7, 79.7, 85.2, $76.2 \mathrm{unit} / \mathrm{mg}$ protein로 $\mathrm{C}$ 군에 비해 $\mathrm{A}$ 군과 $\mathrm{WA}$ 군의 $\mathrm{SOD}$ 활성은 높았으 나(p<0.05), RA군과는 유의적인 차이는 없었다. 그러나 뇌 조직에서의 $\mathrm{SOD}$ 활성은 $\mathrm{C}$ 군, $\mathrm{A}$ 군, $\mathrm{WA}$ 군, $\mathrm{RA}$ 군은 각각 105.6, 91.7, 94.4, 103.2 unit/mg protein로 혈청과는 반대로 
$\mathrm{C}$ 군에 비해 A군과 WA군에서 낮았으나(p<0.05), RA군과 는 유의적인 차이는 없었다.

Keen 등(33)은 급성 및 만성적으로 알코올을 공급하였을 때, 미토콘드리아에서 $\mathrm{O}_{2}^{-}$의 생성과 함께 $\mathrm{SOD}$ 의 활성이 증가되었으며, Hilton 등(34)은 알코올 섭취로 인한 SOD 활성의 증가 반응은 알코올 공급으로 생성된 $\mathrm{O}_{2}^{-}$를 제거하 려는 생리적응 현상의 하나로 설명하였다. 그 반면에 $20 \%$ 알코올 액체식이를 공급할 경우, 시간이 경과함에 따라 체 내 $\mathrm{O}_{2}^{-}$대사에 $\mathrm{SOD}$ 효소가 작용하여 $\mathrm{SOD}$ 효소 활성이 저하되었다는 상반된 연구결과도 있다(35). 알코올의 산화 적 스트레스 반응에 대한 SOD 활성의 상반된 반응 결과는 생체 조직에서의 $\mathrm{O}_{2}^{-}$의 생성 정도, 항산화 영양소 및 생리활 성 성분인 polyphenol이나 flavonoid이나 알코올 종류, 생체 조직 부위 및 항상성 조절 능력 등에 따라 다양한 반응을 보이는 것으로 추측된다. 그러나 본 실험에서 알코올 섭취 에 대한 SOD 항산화 방어 효소 활성은 무알코올 섭취군에 비해 담금 소주와 백하수오 담금주를 섭취했을때 혈장에서 유도된 반면에, 뇌 조직에서는 낮은 효소 활성을 보였다. 그러나 적하수오 담금주를 섭취했을때 SOD 활성은 혈장과 뇌 조직 모두에서 무알코올 섭취군 수준으로 나타났다.

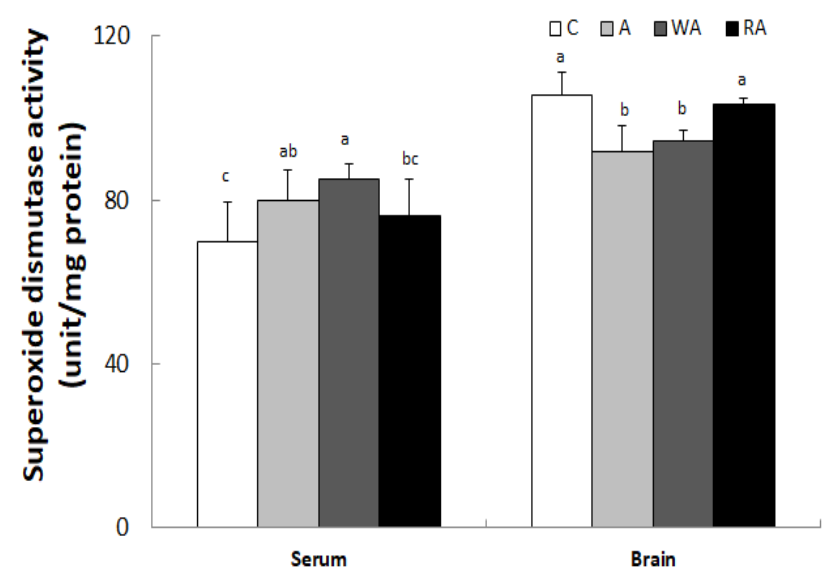

Fig. 3. Influences of chronical Cynanchi Wilfordii Radix and Polygoni Multiflori Radix liquors ingestion on serum and brain SOD activities in rats.

C, normal liquid diet; A, 25\% Soju addition to liquid diet; WA, 25\% Cynanchum Wilfordii Radix liquor addition to liquid diet; RA, 25\% Polygoni Multiffori Radix liquor addition to liquid diet.

Values are means \pm S.D., $N=10$, Values with different alphabet are significantly different at $\mathrm{p}<0.05$ by Duncan's multiple range test.

\section{Catalase 활성}

혈청과 뇌 조직의 catalase 활성은 Fig. 4 와 같다. 혈청에서 는 $\mathrm{C}$ 군, $\mathrm{A}$ 군, $\mathrm{WA}$ 군, $\mathrm{RA}$ 군은 각각 $3.71,3.71,4.32,4.12$ unit/mg protein로 나타났다. C군 및 $\mathrm{A}$ 군에 비해 WA군의 catalase 활성은 $\mathrm{p}<0.05$ 수준에서 유의적으로 높았으나, WA 군과 RA군 간의 catalase 활성은 유의미한 차이는 없었다. 뇌 조직의 catalase 활성은 $\mathrm{C}$ 군, $\mathrm{A}$ 군, $\mathrm{WA}$ 군, $\mathrm{RA}$ 군은 각각
$4.09,1.84,0.98,0.95$ unit/mg protein로 $\mathrm{C}$ 군에 비해 A군은 $55.0 \%$, WA군은 $76.3 \%$, 그리고 $\mathrm{RA}$ 군은 $76.8 \%$ 정도 유의적 으로 낮은 효소 활성을 보였다 $(\mathrm{p}<0.05)$.

체내 항산화 효소로 $\mathrm{SOD}$ 는 반응성이 크고 독성이 강한 $\mathrm{O}^{2-}$ 을 $\mathrm{H}_{2} \mathrm{O}_{2}$ 로 바꾸는 작용을 하며, 이 과정에서 생성된 $\mathrm{H}_{2} \mathrm{O}_{2}$ 와 MDA로부터 생체를 보호하기 위해서 catalase나 GSH-Px 효소는 $\mathrm{H}_{2} \mathrm{O}_{2}$ 와 $\mathrm{MDA}$ 를 $\mathrm{H}_{2} \mathrm{O}$ 로 무독화 시킨다. 급만성적으 로 섭취된 알코올은 생체 내에서 catalase 활성을 유도하여 $\mathrm{MDA}$ 를 분해하거나 알코올의 대사과정에서 만들어진 $\mathrm{H}_{2} \mathrm{O}_{2}$ 를 제거함으로써 알코올 섭취에 따른 산화 스트레스에 대한 항상성을 유지한다(36). 본 실험의 연구결과에서도 혈청 내 catalase 활성 수치가 가장 높은 WA군에서 catlase 효소에 의한 $\mathrm{MDA}$ 의 분해 작용으로 $\mathrm{MDA}$ 함량이 낮은 것으 로 추측된다. 또한 catalase 효소는 알코올을 acetaldehyde로 분해시키는 반응에도 관여하며, Yun 등(37)의 보고에서는 천마침출약용주를 6주 동안 섭취시킨 SD 흰쥐의 catalse 활성은 알코올 섭취량이 높을수록 증가한 반면에, 담금 소 주의 알코올 섭취량이 높을수록 catalase 활성은 낮은 경향 을 보였다. 또한 Kinard 등(38)의 연구에 의하면 만성적 알 코올 투여로 catalase 활성이 유의적으로 유도되지만, 만성 적 혹은 고용량의 급성적 알코올의 섭취가 catalase 활성 유도에 별다른 영향을 주지 못했다는 상반된 보고도 있다(39).

본 실험에서 6주간의 만성적 알코올 섭취에 대한 항산화 효소로 catalase 활성은 무알코올이나 담금 소주 섭취군에 비해 혈장에서는 백하수오 담금주 섭취군에서 유도된 반면 에, 뇌 조직에서는 알코올을 섭취한 모든 군에서 무알코올 섭취군에서 비해 낮은 catalase 활성을 보였다. 이때 혈장과 뇌 조직 모두에서 백하수오와 적하수오 담금주 섭취군 간에 비슷한 catalase 활성을 보였다.

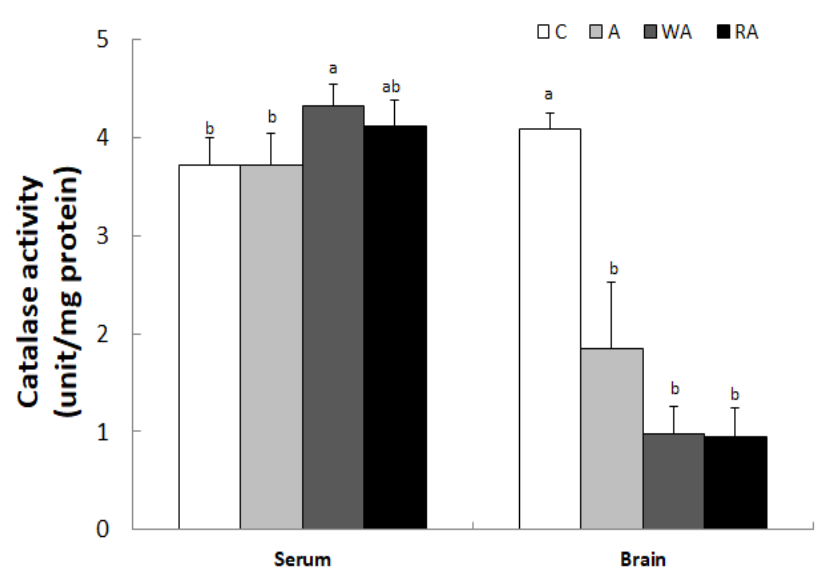

Fig. 4. Influences of chronical Cynanchi Wilfordii Radix and Polygoni Multiflori Radix liquors ingestion on serum and brain catalase activities in rats.

C, normal liquid diet; A, 25\% Soju addition to liquid diet; WA, 25\% Cynanchum Wilfordii Radix liquor addition to liquid diet; RA, 25\% Polygoni Multiflori Radix liquor addition to liquid diet.

Values are means \pm S.D., $N=10$, Values with different alphabet are significantly different at $\mathrm{p}<0.05$ by Duncan's multiple range test. 


\section{Glutathione-s-transferase 활성}

혈청과 뇌 조직의 GST 활성은 Fig. 5와 같다. C군, A군, WA군, RA군의 GST 활성은 각각 $0.58,0.56,0.54,0.47$ unit/mg protein로 $\mathrm{C}$ 군과 $\mathrm{A}$ 군 간의 $\mathrm{GST}$ 활성은 유의한 차이 는 없었다. 그러나 $\mathrm{C}$ 군의 $\mathrm{GST}$ 활성에 비해 WA군과 RA군 에서 유의적으로 낮은 GST 활성을 보였다(p<0.05). 뇌 조직 에서 $\mathrm{C}$ 군, $\mathrm{A}$ 군, $\mathrm{WA}$ 군, $\mathrm{RA}$ 군의 $\mathrm{GST}$ 활성은 각각 1.42 , $1.74,1.59,1.57$ unit/mg protein로 C군의 GST 활성에 비해 $\mathrm{A}$ 군에서는 $18.4 \%, \mathrm{WA}$ 군에서는 $22.5 \%, \mathrm{RA}$ 군에서는 $12.0 \%$ 정도의 활성이 유도되었다 $(\mathrm{p}<0.05)$.

Glutathione-s-transferase는 체내에서 알코올과 같은 산화 적 스트레스가 가해질 때, GSH와 GSH-Px 활성과 함께 유도 되어 자유라디칼 제거 반응으로 산화적 세포 손상에 대한 방어작용을 나타내는 효소로서, $\mathrm{MDA}$ 의 제거 및 무독화 반응에 관여하는 중요한 효소이다(40). GST는 생체막에 결합된 $\mathrm{MDA}$ 제거를 위해 catalase 효소와 함께 활성 증가가 유도된다고 Aykac 등(39)은 보고하였으며, Yoon 등(41)은 $\mathrm{SD}$ 흰쥐에게 $6 \%$ 알코올 및 $6 \%$ 알코올과 동시에 $2 \mathrm{~g} / \mathrm{kg}$ B.W.의 구기자 에탄올 추출물을 2 개월간 음용시킨 실험동 물의 간 조직에서 GST 활성을 분석한 결과, 알코올만 섭취 한 실험군에 비하여 항산화 활성이 있는 구기자 에탄올 추출물을 투여한 실험동물에서 GST 활성 유도 현상을 관찰 하였다. 본 연구에서 산화적 손상에 대한 항산화 방어 효소 로 GST 활성은 혈청에서는 무알코올 섭취군에 비해 백하수 오 및 적하수오 담금주 섭취군에서 낮은 활성을 보였다. 그러나 뇌 조직에서는 무알코올 섭취군에 비해 $\mathrm{MDA}$ 수준 이 높은 담금 소주, 백하수오 및 적하수오 담금주를 섭취군 에서 GST 효소의 활성이 유도된 것으로 나타났다.

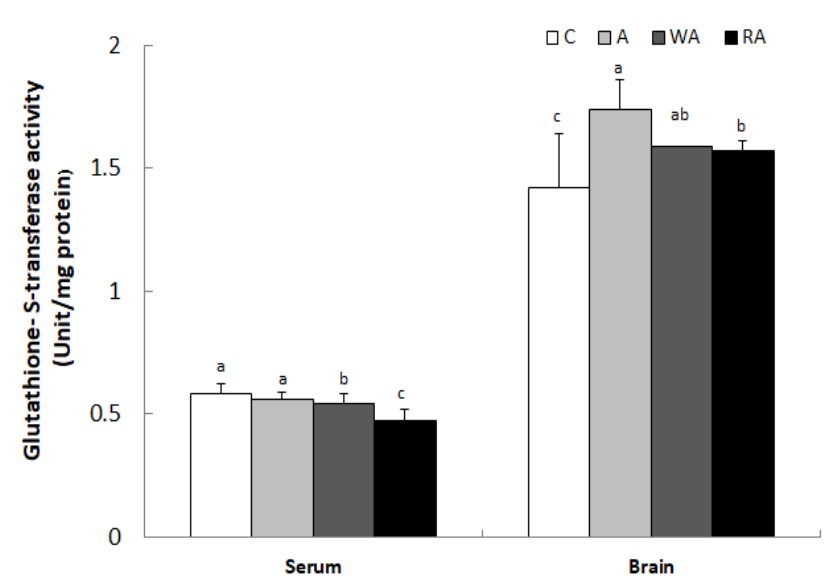

Fig. 5. Influences of chronical Cynanchi Wilfordii Radix and Polygoni Multiflori Radix liquors ingestion on serum and brain GST activities in rats.

C, normal liquid diet; A, 25\% Soju addition to liquid diet; WA, 25\% Cynanchum Wilfordii Radix liquor addition to liquid diet; RA, 25\% Polygoni Multiffori Radix liquor addition to liquid diet.

Values are means $\pm S . D$., $N=10$, Values with different alphabet are significantly different at $\mathrm{p}<0.05$ by duncan's multiple range test.

\section{Glutathione peroxidase 활성}

혈청과 뇌 조직의 GSH-Px 활성은 Fig. 6과 같다. 혈청에 서의 $\mathrm{GSH}-\mathrm{Px}$ 활성은 $\mathrm{C}$ 군, $\mathrm{A}$ 군, WA군, $\mathrm{RA}$ 군은 각각 34.1, 43.8, 42.1, 39.3 unit/mg protein으로 $\mathrm{C}$ 군에 비해 $\mathrm{A}$ 군과 WA 군에서 $\mathrm{p}<0.05$ 수준에서 유의적인 증가를 보였다. 그러나 뇌 조직의 $\mathrm{GSH}-\mathrm{Px}$ 활성은 $\mathrm{C}$ 군 $\mathrm{A}$ 군, $\mathrm{WA}$ 군, $\mathrm{RA}$ 군은 각각 $3.09,1.64,2.85,2.97 \mathrm{unit} / \mathrm{mg}$ protein으로 $\mathrm{C}$ 군에 비해 $\mathrm{A}$ 군에 서 $\mathrm{p}<0.05$ 수준에서 유의적으로 낮은 활성을 보인 반면에, $\mathrm{C}$ 군, WA군 및 RA군의 GSH-Px 활성은 유의적인 차이가 없었다.

Glutathione peroxidase는 DNA 합성물질 이동, 효소 활성 조절 및 $\mathrm{GSH}$ 를 전자공여제로 이용하여 $\mathrm{H}_{2} \mathrm{O}_{2}$ 를 환원시켜 제거함으로서 세포 손상의 예방 등에 직·간접적으로 작용 한다(42). GSH-Px는 Se를 함유하는 항산화계 효소로서 $\mathrm{MDA}$ 와 $\mathrm{H}_{2} \mathrm{O}_{2}$ 의 무독화를 촉매하며 철분, 비타민 $\mathrm{E}$ 및 필수 지방산의 결핍 시 그 활성이 감소되고 산화 스트레스로 그 활성이 증가하는 것으로 알려져 있다(43). 급성 알코올을 투여한 실험에서 간 조직에서 알코올에 의한 독성으로 인하 여 $\mathrm{GSH}$ 수준을 증가시킨다고 보고하고 있으며, 그 중 $\mathrm{GSH}$ 의 직접적인 전구물질인 S-adenosyl methionine의 경구 투여 는 만성 알코올 섭취로 인한 손상된 간 조직 내에서 $\mathrm{GSH}$ 의 활성을 회복시키는 것으로 보고하였다(44). 본 실험에서 세포 손상에 대한 항산화 방어 효소로 혈청 내 GSH-Px 활성은 무알코올 섭취군에 비해 담금 소주와 백하수오 담금 주 섭취군에서 유도되었으며, 뇌 조직에서는 담금 소주 섭 취군에 비해 백하수오 담금주 및 적하수오 담금주 섭취군에 서는 GSH-Px 효소의 높은 활성을 보였다.

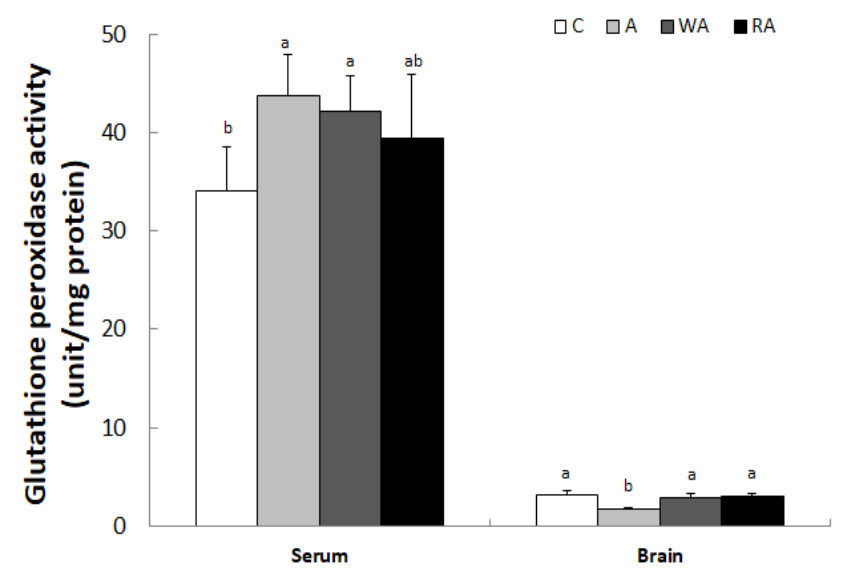

Fig. 6. Influences of chronical Cynanchi Wilfordii Radix and Polygoni Multiflori Radix liquors ingestion on serum and brain GSH-Px activities in rats.

C, normal liquid diet; A, 25\% Soju addition to liquid diet; WA, 25\% Cynanchum Wilfordii Radix liquor addition to liquid diet; RA, 25\% Polygoni Multiflori Radix liquor addition to liquid diet.

Values are means \pm S.D., $N=10$, Values with different alphabet are significantly different at $p<0.05$ by Duncan's multiple range test. 


\section{Total antioxidant activity}

혈청과 뇌 조직의 $\mathrm{TAC}$ 는 $\mathrm{Fig}$. 7과 같다. 혈청은 $\mathrm{C}$ 군, $\mathrm{A}$ 군, $\mathrm{WA}$ 군, $\mathrm{RA}$ 군은 각각 $4.44,3.73,4.70,4.61 \mathrm{nmol} / \mu \mathrm{L}$ 로 $\mathrm{C}$ 군의 $\mathrm{TAC}$ 에 비해 $\mathrm{A}$ 군이 유의적으로 낮았다( $\mathrm{p}<0.05)$. 그 러나 C군, $\mathrm{WA}$ 군, $\mathrm{RA}$ 군 간의 $\mathrm{TAC}$ 는 유의한 차이가 없었다. 뇌 조직에서 $\mathrm{TAC}$ 는 $\mathrm{C}$ 군, $\mathrm{A}$ 군, $\mathrm{WA}$ 군, $\mathrm{RA}$ 군은 각각 0.40 , $0.30,0.36,0.29 \mathrm{nmol} / \mathrm{LL}$ 로 $\mathrm{C}$ 군의 $\mathrm{TAC}$ 에 비해 $\mathrm{A}$ 군과 $\mathrm{RA}$ 군 에서 유의적으로 낮아지만(p<0.05), $\mathrm{C}$ 군과 $\mathrm{WA}$ 군 간의 $\mathrm{TAC}$ 는 유의한 차이는 없었다. 알코올에 의한 산화적 스트 레스는 항산화 효소의 활성 또는 전자전달계의 환원력 등 세포의 항산화력에 의해 조절되며, $\mathrm{TAC}$ 는 식사를 통해 섭 취한 flavonoid, carotenoid 등의 phytochemical과 비타민 A, 비타민 C, 비타민 E 등 항산화 비타민의 체내 항산화력에 대한 포괄적 능력 지표로서 중요한 의미를 가지고 있다(45). 2010년 국민건강영양조사에 근거한 매실가공품 섭취로부 터 한국인의 일인당 하루 총 phenol, 총 flavonoid 및 항산화 능 섭취량으로 TAC를 추정할 수 있는 Lee 등(45)가 있다. 본 연구 결과에서 알코올 섭취에 대한 총 항산화 방어력으 로 혈청에서 담금 소주 섭취군에 비해 백하수오 및 적하수 오 담금주 섭취군에서 $\mathrm{TAC}$ 가 높았으며, 이는 담금 소주는 갖고 있지 못한 총 phenol과 총 flavonoids를 백하수오 담금 주 및 적하수오 담금주가 함유하고 있는 결과 때문인 것으 로 추측된다. 그러나 뇌 조직에서는 담금 소주, 백하수오 담금주 및 적하수오 담금주 간의 $\mathrm{TAC}$ 에 유의한 차이가 없는 것은 체내 $\mathrm{MDA}$ 수준이나 항산화 효소 활성 등 체내 산화 및 항산화 물질의 수준 차이에 따른 결과로 추측된다.

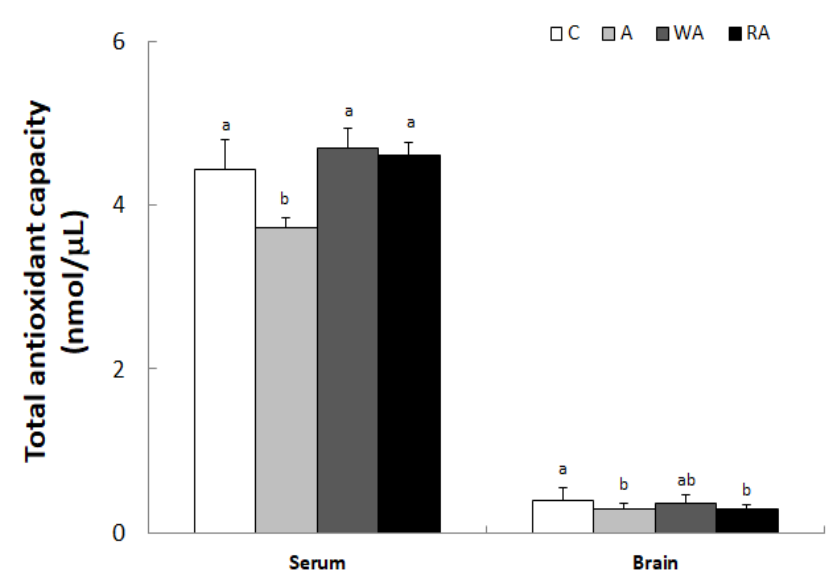

Fig. 7. Influences of chronical Cynanchi Wilfordii Radix and Polygoni Multiflori Radix liquors ingestion on serum and brain TAC levels in rats.

C, normal liquid diet; A, 25\% Soju addition to liquid diet; WA, 25\% Cynanchum Wilfordii Radix liquor addition to liquid diet; RA, 25\% Polygoni Multiflori Radix liquor addition to liquid diet.

Values are means \pm S.D., $N=10$, Values with different alphabet are significantly different at $p<0.05$ by Duncan's multiple range test.

\section{요 약}

본 연구는 백하수오와 적하수오 담금주가 흰쥐의 혈청과 뇌 조직의 $\mathrm{MDA}$ 수준 및 항산화 활성에 미치는 영향을 알아보고자 10 주령의 수컷 $\mathrm{SD}$ 흰쥐를 이용하여 전체 실험 식이의 열량에 $12 \%$ 가 담금 소주, 백하수오 및 적하수오 담금주가 포함된 액체식이를 제조하여 6주간 공급하였다. 실험군은 무알코올 섭취군(C)군, 담금 소주 섭취(A)군 그리 고 백하수오 담금주 섭취(WA)군, 적하수오 담금주 섭취군 (RA)군으로 나누었으며, 그 결과는 다음과 같다. 혈청의 $\mathrm{MDA}$ 함량은 $\mathrm{C}$ 군과 $\mathrm{WA}$ 군에서 유의한 차이가 없었으며, 뇌 조직에서 $\mathrm{MDA}$ 함량은 $\mathrm{C}$ 군, $\mathrm{WA}$ 군 및 $\mathrm{RA}$ 군 간에 유의한 차이가 없었다. 뇌 조직에서의 $\mathrm{NO}$ 생성능은 실험군 중에서 $\mathrm{RA}$ 군에서 유의미한 낮은 수치를 보였다. 항산화 효소 중에 서 $\mathrm{SOD}$ 는 혈청에서는 $\mathrm{C}$ 군에 비해 $\mathrm{A}$ 군과 $\mathrm{WA}$ 군에서 높은 활성을 보였으며, 뇌 조직에서는 $\mathrm{C}$ 군에 비해 $\mathrm{A}$ 군과 $\mathrm{WA}$ 군 에서 낮은 활성을 보였다(p<0.05). Catalase 활성은 $\mathrm{C}$ 군에 비해 혈청에서는 WA군에서 높은 활성 수치를 보인 반면에, 뇌 조직에서는 $\mathrm{A}$ 군, $\mathrm{WA}$ 군 및 $\mathrm{RA}$ 군에서 낮은 활성을 보였 다(p<0.05). GSH-Px은 $\mathrm{C}$ 군에 비해 $\mathrm{A}$ 군과 $\mathrm{WA}$ 군에서 높은 활성을 보였으나(p<0.05), 뇌 조직에서는 $\mathrm{C}$ 군에 비해 $\mathrm{A}$ 에 서 낮은 활성을 보였다(p<0.05). 혈청에서의 $\mathrm{TAC}$ 는 $\mathrm{A}$ 군에 비해 WA군과 RA군에서 높았다.

이상의 연구 결과에서는 생체 내 혈청과 뇌 조직 부위에 따른 차이는 있으나 하수오 담금주의 섭취가 $\mathrm{MDA}$ 수준 및 $\mathrm{NO}$ 생성 억제와 $\mathrm{TAC}$ 유도에 긍정적인 영향을 미친것으 로 보여진다. 또한 항산화 효소 중에서 혈청 내 SOD, catalse 및 GSH-Px 효소는 적하수오 섭취군에 비해 백하수오 섭취 군에서 유의미하게 높은 활성을 보여 주었다. 그러나 향후 산화적 손상에 대한 뇌 조직에서 보호효과를 얻기 위한 올바른 약용주 섭취를 위해서는 약용주의 유효성분과 이들 함량과 체내 과산화지질 수준, 항산화 효소 활성 및 항산화 영양소와의 관련성 등에 대한 세밀한 연구가 필요한 것으로 사료된다.

\section{감사의 글}

이 논문은 2016학년도 대구한의대학교 기린연구년 수행 과제로 연구된 것으로 이에 감사드립니다.

\section{Reference}

1. Sies H (1986) Biochemistry of oxidative stress. Angew Chem Int Ed Engl, 25, 1058-1071

2. Kim DH, Park HJ, Jung JW, Lee SH (2017) Effect of 
the extract of hydrangea dulcis folium on alcohol-induced psychiatric deficits. J Life Sci, 27, 355-360

3. Dodd PR, Beckmann AM, Davidson MS, Wilce PA (2000) Glutamate-mediated transmission, alcohol, and alcoholism. Neurochem Int, 37, 509-533

4. Spinetta MJ, Woodlee MT, Feinberg LM, Stroud C, Schallert K, Cormack LK, Schallert T (2008) Alcohol induced retrograde memory impairment in rats: prevention by caffeine. Psychopharmacology, 201, 361-371

5. Chandler LJ, Sutton G, Norwood D, Sumners C, Crews FT (1997) Chronic ethanol increases N-methyl-Daspartate-stimulated nitric oxide formation but not receptor density in cultured cortical neurons. Mol Pharmacol, 51, 733-740

6. Kasdallah-GA, Mornagui B, Aouani E, Hammami M, Gharbi N, Kamoun A, El-Fazaa S (2006) Protective effect of resveratrol on ethanol-induced lipid peroxidation in rats. Alcohol Alcoholism, 41, 236-239

7. Kong HJ, Shin SR, Hwang SJ, Lee KE, Jang JH, Yang KM (2016) Effects of Polygoni multiflori radix liquors on the memory impairment of rat. Culi Sci Hos Res, $22,128-142$

8. Cui K, Luo X, Xu K, Ven Murthy MR (2004) Role of oxidative stress in neurodegeneration: recent developments in assay methods for oxidative stress and nutraceutical antioxidants. Prog Neuropsychopharmacol Biol Psychiatry, 28, 771-799

9. Chen C, Wei T, Gao Z, Zhao B, Hou J, Xu H, Xin W, Packer L (1999) Different effects of the constituents of EGb761 on apotosis in rat cerebellar granule cells induced by hydroxyl radicals. Biochem Mol Biol Int, 47, 397-405

10. Lee DU, Shin US, Huh K (1998) Structure-activity relationship of gagaminine and its derivatives on the inhibition of hepatic aldehyde oxidase activity and lipid peroxidation. Arch Pharmacal Res, 21, 273-277

11. Na MK, Park JY, An RB, Lee SM, Kim YH, Lee JP, Seong RS, Lee KS, Bae KH (2000) Quality evaluation of Polygoni Multiflori Radix. Korean J Pharmacogn, 31, 335-339

12. Chang CH, Lin CC, Yang JJ, Namba T, Hattori M (1996) Anti-inflammatory effects of Emodin from Ventilago leiocarpa. Am J Chin Med, 24, 139-142

13. Kuo YC, Sun CM, Ou JC, Tsai WJ (1997) A tumor cell growth inhibitor from polygonum hypoleucum Ohwi. Life Sci, 61, 2335-2344
14. Yen GC, Chen HW, Duh PD (1998) Extraction and identification of an antioxidative component from Jue Ming Zi (Cassia tora L). J Agric Food Chem, 46, 820-824

15. Hatano $T$, Uebayashi $H$, Ito $H$, Shiota $S$, Tsuchiya $T$, Yoshida T (1999) Phenolic constituents of cassia seeds and antibacterial effect of some naphthalenes and anthraquinones on methicillin-resistant Staphylococcus aureus. Chem Pharm Bull, 47, 1121-1127

16. Wang W, Cao CY, Wang DQ, Zhao DZ (2006) Effect of prepared Polygonum multiflorum on striatum extracellular acetylcholine and choline in rat of intracerebral perfusion with sodium azide. China J Chin Mater Med, 31, 751-753

17. Lee SE, Lee JH, Kim GS, Hong YP, Noh HJ, Park CG, Kim SY (2012) Effect of root extract of Lythrum salicaria L. on liver function of rat acutely administrated with alcohol. Korean J Medicinal Crop Sci, 20, 345-352

18. Na YI (2001) Effect of Cynanchum wilfordii Hemsley extract on lipid peroxidation and antioxidative enzyme activities in rats. MS Thesis, Sook Myung Woman's University, Korea, p 34-36

19. Choi DH (2007) Effects of an ethanol extract of Cynanchum wilfordii on vascular dysfunction in animals fed high fat diet. Ph D Thesis, Won Kwang University, Korea, p 48-50

20. Kim KS, Yeon JH, Lee HJ, Yun HS, No JG, Song IG (2009) Quality characteristics of Yakju with Polygoni multiflori radix additives. Paper presented at International Symposium of Korean Society of Food Science and Nutrition, November 11, Changwon, Korea

21. Park HJ, Kim DI, Lee SH, Lee YM, Jeong HJ, Cho SM, Chun HK, Lillehoj HS (2005) Supplementary effects of Lentinus edodes with different harvest period and part on neurotransmitters and lipid peroxide levels in the brain of diabetic mice. J Korean Soc Food Sci Nutr, 34, 1182-1187

22. Won BY, Shin KY, Ha HJ, Chang KA, Yun YS, Kim YR, Park YJ, Lee HG (2015) Effect of dropwort (Oenanthe javanica) extracts on memory improvement in Alzheimer' disease animal model, Tg2576 mice. Korean J Food Sci Technol, 47, 779-784

23. Hwa GP (2011) Manufacturing method of Polygonum multiflorum Korea Patent No. 1020110082722

24. Lieber CS, Decarli LM (1986) The feeding of ethanol in liquid diet. Alcoholism: Clin Exp Res, 10, 550-553

25. Jo SM, Jeong YJ, Sohn EH, Chang KJ, Koo HJ, Kang SC (2015) Inhibitory effect of Cynanchum wilfordii on 
nonalcoholic fatty liver disease development in mice. Paper presented at 2015 Annual Meeting of Korea Society of Plant Resources, April 24, Andong, Korea

26. Lee SJ, Kong JR, Hwang CL, Sin YU, Seong NJ (2010) Antioxidant activity of Polygonum multiflorum Thunb solvent extract. Paper presented at 2015 International Symposium and Annual Meeting of Korea Society of Food Science and Nutrition, October, 27, Daegu, Korea

27. Seo H, Seo GY, Ko SZ, Park YH (2011) Inhibitory effects of ethanol extracts from Polygoni multiflori radix and Cynanchi wilfordii radix on melanogenesis in melanoma cells. J Korean Soc Food Sci Nutr, 40, 1086-1091

28. Lee MK, Yeo HS, Kim JW, Markelonis GJ, Oh TH, Kim YC (2000) Cynandione A from Cynanchum wilfordii protects cultured cortical neurons from toxicity induced by $\mathrm{H}_{2} \mathrm{O}_{2}$, L-glutamate, and kainate. J Neurosci Res, 59, 259-264

29. Choi Jh, Lee HS, Kim YG, Kim BM, Kim IH, Lee CH (2012) Effect of Polygonum multiflorum thunberg extract on lipid metabolism in rats fed high-cholesterol diet. J Korean Soc Food Sci Nutr, 41, 957-962

30. Shin MK (1985) A comparative study on the effects of Polygoni radix and Cynanchi radix on rat livers intoxicated with carbon tetrachloride. Kor J Pharmacogn, $16,81-92$

31. Mecocci P, MacGarvey U, Beal MF (1994) Oxidative damage to mitochondrial DNA is increased in Alzheimer's disease. Ann Neurol, 36, 747-751

32. Kim HY, Kim JY, Cho EJ, Choi JM, Hwang CE, Lee HY, Ahn MJ, Lee JH, Kim YG, Ko KH, Goo YM, Oh KY, Cho KM (2015) Free radical scavenging effect and oxidative stress protective activity of domestic processed Polygoni Multiflori Radix J Korean Soc Food Sci Nutr, 44, 809-815

33. Keen CL, Tamura T, Lonnerdal B, Hurley LS, Halsted $\mathrm{CH}$ (1985) Changes in hepatic superoxide dismtase activity in alcoholic monkeys. Am J Clin Nutr, 41, 929-932

34. Hilton JW, Hodson PV, Slinger SJ (1980) The requirement and toxicity of selenium in rainbow trout (Salmo gairdneri). J Nutr, 110, 2527-2535

35. Nadkarni GD, D'Souza NB (1988) Antioxidant and free radical scavenging enzymes in chronically ethanolconsuming rats: controversy over hepatic lipid peroxidation. Drug Alcohol Depend, 22, 161-164
36. Antonenkov VD, Panchenko LF (1988) Effect of chronic ethanol treatment under partial catalase inhibition on the activity of enzymes related to peroxide metabolism in rat liver and heart. Int $\mathrm{J}$ Biochem, 20, 823-828

37. Yun IJ, Kong HJ, Jang JH, Yang KM (2016) Effects of chronic consumption of liquor prepared with Gastrodiae rhizoma on antioxidant activity in brain tissue of rats. J East Asian Soc Diet Life, 26, 531-542

38. Kinard FW, Nelson GH, Hay MG (1956) Catalase activity and ethanol metabolism in the rat. Proc Soc Exp Bio Med, 92, 772-773

39. Aykac G, Uysal M, Yacin AS, Sivas A, Toker NK, Sivas A, Oz H (1985) The effect of chronic ethanol ingestion on hepatic lipid peroxide, glutathione, glutathione peroxidase and glutathione transferase in rat. Toxicology, $36,71-76$

40. Jung CS, Jung JH, Jung KH (2000) The effect of propolis on endotoxin-induced thrombosis. Biomol Ther, 8, 223-227

41. Yoon CG, Jeon TW, Oh MJ, Lee GH, Jeong JH (2000) Effect of the ethanol extract of lycium chinense on the oxygen free radical and alcohol metabolizing enzyme activities in rats. J Korean Soc Food Sci Nutr, 29, 268-273

42. Casini AF, Pompella A, Comporti M (1984) Glutathione depletion, lipid peroxidation, and liver necrosis following bromobenzene and iodobenzene intoxication. Toxicol Pathol, 12, 295-299

43. Huh K, Park JM, Lee SI (1985) Garlic effect on the glutathione S-transferase and glutathione peroxidase. Arch Pharm Res, 8, 197-203

44. Mato JM, Camara J, Femndez de Paz J, Caballera L, Coll S, Caballero A, Garcia Buey L, Beltran J, Benita V, Caballeria J, Sola R, Moreno-Otero R, Barrao F, Martn-Duce A, Correa JA, Pars A, Barrao E, Garea-Magaz 1, Puerta JL, Moreno J, Boissard G, Oriz P, Rods J (1999) S-adenosylmethionine in alcoholic liver cirrhosis: a randomized, placebo-controlled, double-blind, multicenter clinical trial. J Hepatol, 30, 1081-1089

45. Lee SH, Song YS, Lee SY, Kim SY, Ko KS (2014) Protective effects of akebia quinata fruit extract on acute alcohol-induced hepatotoxicity in mice. Korean J Food Sci Technol, 46, 622-629 